\title{
Biological Studies on the Two Predaceous Mites, Phytoseiulus macropilis (Banks) and Typhlodrompis capisicum Mostafa
}

\author{
Dalia, A. Waked \\ Plant Protec. Res. Inst., Agric. Res. Center. Dokki, Giza, Lgypt.
}

\begin{abstract}
The biology of Phytoseiulus macropilis andTyphlodrompis capisicum fed on three preys: Tetranychus urticae, Panonychus ulmi and Eutetranychus oriantalis was studied at $27^{\circ} \mathrm{C}$. Total consumption, as well as predation capacity was estimated. T. urticae was more favorable than the other preys for $P$. macropilis, its fecundity was $(31.06,20.53$ and 13.93eggs for 7 . urticae, E. oriantalis and P. ulmi, respectively. No signilicant differences in the fecundity of T. capisicum when fed on $T$. urticae and $E$. oriantalis, 21.38 and 19.73 eggs, respectively. The life cycle duration was shorter(11.60 days) when $P$. macropilis fed on T. urticae than the other two preys, 17.93 days and 21.40 days for E. oriantalis and $P$. $u l m i$, respectively; while no significant differences in life cycle duration of $T$. capisicum when fed on $T$. urticae and $E$. oriantalis being shorter compared with feeding on $P$. $u / m i$ which increased the life cycle. The consumption rate of predators increased with increasing prey densities at three levels 5,10 and 15 individuals for both predators. Also. deposited eggs of the two predators increased by increasing food.Net reproductive rate $\left(R_{0}\right)$ and Intrinsic rate of increase $\left(\mathrm{r}_{\mathrm{m}}\right)$ values were the best values when $P$. macropilis led on $T$. urticae and the mean generation time $(\mathrm{T})$ decreased compared with the other preys.
\end{abstract}

Key words: Phytoseiulus macropilis; Typhlodrompis capisicum; Biology;Different preys.

\section{INTRODUCTION}

The phytoseiids are the most studied because plant inhabiting predatory mites of their importance in the control of phytophagous mites on agricultural crops, Helle and Sabelis (1985). Many predaceous phytoseiids are now used as biological control agents in various agricultural ecosystems being important predators of phytophagous mites populations in IPM programs outdoor and greenhouse crops. Phytoseiulus species all have probably highest potential for population increase, in the Phytoseiidae Zhang (1995). They have a short development time, Sabelis and Janssen (1994), along with high fecundity, resulting in intrinsic rate of increase (r) values sometimes exceeding 0.4 Takahashi and Chant (1992).

Phytoseiulus macropilisis one of the most important generalist indigenous predators of tetranychids and widely found on various crops. Thus, the aim of this study was to investigate the biological life table and intrinsic rate of natural increase of $P$. macropilis and $T$. capisicum at three food types of mite species, Tetranychus urticae, Panonychus ulmi and Eutetranychus oriantalis.

\section{MATERIALS AND METHODS}

\section{Feeding of predace ous mites on diffe rent preys of phytophagous mites:}

Seminated newly adult females of predaceous mites, T. capisicum, and $P$. macropilis were transferred singly from the established culture to leaf mulberry discs, one inch in diameter as each rearing arenas in Petri-dishes on water saturated cotton.
Every female was supplied with sufficient known number of the prey (adult of phytophagous mites, $T$. urticae, E. oriantalis and $P$. ulmi). Petri-dishes were placed in an incubator at $27 \pm 2^{\circ} \mathrm{C}$ and $65 \pm 5 \%$ R.H. Adult longevity, fecundity and rate of consumption were calculated.

\section{Effect of prey density on egg laying, longevity and} feeding behavior of predace ous mites:

Stock laboratory cultures of the predatory mite species, $P$. macropilis and $T$. capisicum were separately maintained on mulberry leaves with $T$. urticae, Basha etal., 2007. Mature virgin females and newly emerged males of the two species (which were within $24-48 \mathrm{hr}$. after the final molt) were given sufficient time to mate on mulberry leaves with abundant preys. The experiments were conducted on upside down mulberry leaf discs of $4 \mathrm{~cm}$ in diameter on water saturated cotton wool pads in Petri- dishes and bordered with wet strip of cotton wool. Adult $T$. urticae females were used as prey in three different densities 5, 10 and 15 per leaf disc. Newly mated females of each predator caged together transferred singly to each leaf disc through three experimental series with $15-20$ replicates individually of each prey density. Leaf discs were examined daily and the number of consumed preys and deposited eggs per two predatory females were registered. All the attcked preys were removed and replaced with alive ones. The experiments were carried out under laboratory conditions of $27 \pm 2^{\circ} \mathrm{C}$ and $65 \pm 5 \%$ R.H.

\section{Life tables:}

An experiment was conducted for the influence of food types on the life table parameters of $P$. macropilis and $T$. capisicum using the most suitable 
prey and calculated according to the life 48 computer program Abou-Setta et al. (1986)

\section{Statis tical analys is:}

Data were subjected to statistical analysis using one way analysis of variance, ANOVA Duncan (1955).

\section{RESULTS AND DISCUSSION}

\section{Feeding on different preys:}

Predaceous mites, $P$. macropilis and $T$. capisicum are considered predators of certain phytophagous mites, T. urticae, E. oriantalis and $P$. ulmi. Data in Table (1) showed that, food consumption of $P$. macropilis female was significantly affected by prey species and stage of the prey i.e. adult of $T$. urticae, E. oriantalis and $P$. ulmi. During adulthood, predator female consumed greater number of adult prey species. T. urticae prey was more favorite compared with the other two preys. Therefore, feeding on $T$. urticae significantly prolonged predator longevity and increased eggs production. The fecundity of $P$. macropilis was 31.06, 20.53 and 13.93 eggs for $T$. urticae, E. oriantalis and $P$. ulmi, respectively. In addition, total devoured prey were obviously increased with fed on T. urticae compared with the other two preys; the consumption of the prey $E$. oriantalis and P. ulmi were similar. P. macropilis fed on $P$. ulmi lived for a shorter period than those fed on the other two. Generally, the highest significant effect on longevity, consumption and fecundity was detected with $T$. urticae. Net reproductive rate $\left(\mathrm{R}_{\mathrm{o}}\right)$ and Intrinsic rate of increase $\left(\mathrm{r}_{\mathrm{m}}\right)$ were the best values when $P$. macropilis fed on $T$. urticae 16.13 times; while were 12.42 times and 7.06 times on $E$. oriantalis and $P$. ulmi, respectively. The mean generation time ( $\mathrm{T}$ ) decreased when fed on T. urticae compared with the other preys. Theintrinsic rate of increase $\left(r_{m}\right)$ was in descending order $0.14,0.11$ and 0.07 individual $/ P /$ day.
Table (2) showed that T. capisicum female the life cycle differed significantly with food types being the shortest, 13.66 days, on T. urticae and the longest, 19.13 days on $P$. ulmi. There was no significance in longevity of $T$. capisicum when fed on the three types of food. Females of T. capisicum gave nearly similar number of deposited eggs when fed on T. urticae 21.38 eggs and E. oriantalis 19.73 eggs; while on $P$. ulmi gave the lowest number 15.90 eggs. Predator female consumed significantly more two-spotted spider mite, 53.15 individuals /female, than $E$. oriantalis 44.18 individuals/female, and P. ulmi 32.41 individuals /female. Net reproduction rate $\left(\mathrm{R}_{\mathrm{o}}\right)$ by was the highest when the predator mite fed on $E$. oriantalis 15.71 times followed by T. urticae 13.54 times and P. ulmi 10.12 times. The intrinsic rate of increase $\left(r_{\mathrm{m}}\right)$ was0.12, 0.11 and 0.08 individualfemale/day when the predator mite, $T$. capisicum fed on T. urticae, E. oriantalis and P. ulmi, respectively. The mean generation time (T) was the highest 20.86 days in P. ulmi; while was near similar in E. oriantalis 17.22 days and T. urticae 18.73 days. These results support the findings of Zaher et al. (2007) who reared Typhlodrompis swirskii on different preys where T. urticae immatures were more favorite than Cenopalpus pulcher and Eutetranychus oriantalis that consumed high number from T. urticae immatures and Van de Vrie and Boersma (1970) for Typhlodrompis potentillae that preferring immatures of the spider mite.

\section{Effect of prey densities on some biological aspects of predacious mites: \\ Consumption, oviposition rates and longevity of} the two predaceous mites, $P$. macropilis and $T$. capisicum reared on mulberry leaf discs. Table (3) showed that consumption rate increased with increasing prey densities at three levels 5,10 and 15 preys for both predators. No significant differences occurred at the rate consumption of levels 10 and 15 preys. The deposited eggs of the two predators increased by increasing offered food. Longevity

Table (1): Life table parameters of $P$. macropilis feeding on $T$. urticae, E. oriantalis and $P$. ulmi

\begin{tabular}{|c|c|c|c|c|}
\hline \multirow{2}{*}{ Biological aspects } & \multirow{2}{*}{ Sex } & \multicolumn{3}{|c|}{ Food } \\
\hline & & T. urticae & E. oriantalis & P. ulmi \\
\hline \multirow{2}{*}{ Life cycle(days) } & 9 & $11.60 \pm 1.34^{\mathrm{c}}$ & $17.93 \pm 1.26^{\mathrm{b}}$ & $21.40 \pm 1.13^{\mathrm{a}}$ \\
\hline & $\delta^{2}$ & $10.20 \pm 1.05^{\mathrm{c}}$ & $15.00 \pm 1.34^{b}$ & $20.73 \pm 1.86^{\mathrm{a}}$ \\
\hline \multirow{2}{*}{ Longevity (days) } & 오 & $19.06 \pm 2.09^{\mathrm{a}}$ & $14.32+1.73^{b}$ & $12.46 \pm 1.92^{b}$ \\
\hline & $\delta$ & $14.13 \pm 1.52^{\mathrm{a}}$ & $10.73 \pm 1.03^{b}$ & $8.20 \pm 0.76^{b}$ \\
\hline \multirow{2}{*}{ Consumption } & 오 & $95.17 \pm 2.91^{\mathrm{a}}$ & $76.54 \pm 2.31^{\mathrm{b}}$ & $69.13 \pm 1.92^{b}$ \\
\hline & $\delta^{2}$ & $67.26 \pm 1.98^{\mathrm{a}}$ & $52.06 \pm 1.57^{\mathrm{b}}$ & $40.53 \pm 1.31^{\mathrm{c}}$ \\
\hline Total eggs/옹 & & $31.06 \pm 2.11^{\mathrm{a}}$ & $20.53 \pm 2.09^{\mathrm{b}}$ & $13.93 \pm 1.29^{c}$ \\
\hline Net reproductive rate $\left(R_{0}\right)$ & & 16.13 & 12.42 & 7.06 \\
\hline Mean generation time (T) & & 17.46 & 19.31 & 22.00 \\
\hline Intrinsic rate of increase $\left(\mathrm{r}_{\mathrm{m}}\right)$ & & 0.14 & 0.11 & 0.07 \\
\hline Expected rate of increase $(\lambda)$ & & 1.20 & 1.17 & 1.16 \\
\hline
\end{tabular}

Means in rows followed by the same letter are not significantly different at $p \leq 5 \% \pm$ standard error. 
Table (2): Life table parameters of T. capisicum fed on T. urticae, E. oriantalis and P. ulmi

\begin{tabular}{|c|c|c|c|c|}
\hline \multirow{2}{*}{ Biological aspects } & \multirow{2}{*}{ Sex } & \multicolumn{3}{|c|}{ Food } \\
\hline & & T. urticae & E. oriantalis & P. ulmi \\
\hline \multirow{2}{*}{ Life cycle(days) } & 9 & $13.66+1.25^{15}$ & $15.40 \pm 1.12^{\mathrm{h}}$ & $19.13 \pm 1.04^{a}$ \\
\hline & $\hat{\sigma}$ & $12.60 \pm 1.17^{b}$ & $12.86 \pm 1.15^{\mathrm{b}}$ & $16.93 \pm 1.24^{\mathrm{a}}$ \\
\hline \multirow{2}{*}{ Longevity (days) } & क & $15.33 \pm 1.32^{\mathrm{a}}$ & $12.40 \pm 1.16^{\mathrm{a}}$ & $13.60 \pm 1.03^{\mathrm{a}}$ \\
\hline & d & $8.80 \pm 0.76^{\mathrm{a}}$ & $7.33 \pm 0.43^{\mathrm{a}}$ & $7.13 \pm 0.23^{\mathrm{a}}$ \\
\hline \multirow{2}{*}{ Consumption } & O & $53.15 \pm 2.34^{\mathrm{a}}$ & $44.18+2.10^{b}$ & $32.41 \pm 2.14^{\mathrm{c}}$ \\
\hline & $\hat{j}$ & $29.53 \pm 1.76 a$ & $22.33 \pm 1.45$ & $14.86 \pm 1.01$ \\
\hline Total eggs / $q$ & & $21.38+1.89^{\mathrm{a}}$ & $19.73 \pm 1.37^{\mathrm{a}}$ & $15.90 \pm 1.81^{b}$ \\
\hline Net reproductive rate $\left(R_{0}\right)$ & & 13.54 & 15.71 & 10.12 \\
\hline Mean generation time $(\mathrm{T})$ & & 18.73 & 17.22 & 20.86 \\
\hline Intrinsic rate of increase $\left(r_{m}\right)$ & & 0.12 & 0.11 & 0.08 \\
\hline Expected rate of increase $(\lambda)$ & & 1.19 & 1.18 & 1.14 \\
\hline
\end{tabular}

Means in rows followed by the same letter are not significantlydifferent at $p \leq 5 \% \pm$ standard error.

Table (3): Influence of three prey levels of $T$. urticae adult on the number of prey consumed, female predator longevity and egg laying

\begin{tabular}{|c|c|c|c|c|c|c|}
\hline \multirow{4}{*}{ P. macropilis } & Prey densities & Total consumption & \multicolumn{2}{|c|}{ Longevity (days) } & \multicolumn{2}{|c|}{ Eggs laid } \\
\hline & 5 & $45.10 \pm 3.07^{6}$ & \multicolumn{2}{|c|}{$10.25 \pm 1.30^{b}$} & \multicolumn{2}{|c|}{$17.20 \pm 0.12^{\mathrm{c}}$} \\
\hline & 10 & $176.47 \pm 5.34^{a}$ & \multicolumn{2}{|c|}{$21.43 \pm 1.25^{\mathrm{a}}$} & \multicolumn{2}{|c|}{$37.73 \pm 1.13^{6}$} \\
\hline & 15 & $180.89 \pm 4.70^{\mathrm{a}}$ & \multicolumn{2}{|c|}{$22.57 \pm 1.06^{\mathrm{a}}$} & \multicolumn{2}{|c|}{$44.52+1.57^{\mathrm{a}}$} \\
\hline L.S.D $5 \%$ & & 15.06 & \multicolumn{2}{|c|}{2.36} & \multicolumn{2}{|c|}{6.01} \\
\hline \multirow{3}{*}{ T. capisicum } & 5 & $39.56 \pm 3.30^{b}$ & \multicolumn{2}{|c|}{$8.68 \pm 1.22^{\mathrm{b}}$} & \multicolumn{2}{|c|}{$15.75 \pm 1.14^{c}$} \\
\hline & 10 & $121.20 \pm 3.50^{\mathrm{a}}$ & \multicolumn{2}{|c|}{$16.50 \pm 1.35^{a}$} & \multicolumn{2}{|c|}{$28.65 \pm 1.13^{6}$} \\
\hline & 15 & $123.62 \pm 2.90^{\mathrm{a}}$ & \multicolumn{2}{|c|}{$19.95 \pm 1.15^{a}$} & \multicolumn{2}{|c|}{$33.06 \pm 1.30^{\mathrm{a}}$} \\
\hline L.S.D $5 \%$ & & 9.12 & \multicolumn{2}{|c|}{4.19} & \multicolumn{2}{|c|}{3.93} \\
\hline \multirow{4}{*}{$\begin{array}{l}\text { P. macropilis }+ \text { T. capisicum } \\
\text { (Caged together) }\end{array}$} & & & P. macropilis & T. capisicum & P. macropilis & T. capisicum \\
\hline & 5 & $36.20 \pm 1.12^{\mathrm{c}}$ & $10.47 \pm 0.95^{\circ}$ & $4.94 \pm 0.87^{\mathrm{b}}$ & $14.37 \pm 1.12$ & $2.56 \pm 0.42$ \\
\hline & & $182.73 \pm 2.53^{a}$ & $19.00 \pm 1.14^{\mathrm{a}}$ & $17.61 \pm 1.35^{\mathrm{a}}$ & $32.61 \pm 1.87$ & $20.48 \pm 1.22$ \\
\hline & 15 & $169.41 \pm 3.08^{6}$ & $20.25 \pm 1.72^{a}$ & $14.20 \pm 1.62^{\mathrm{a}}$ & $43.09 \pm 2.36$ & $27.67 \pm 1.47$ \\
\hline L.S.D ${ }_{5 \%}$ & & 10.11 & 6.34 & 4.62 & & \\
\hline
\end{tabular}

Means in columns followed by the same letter are not significantly different at $p \leq 5 \% \pm$ standard error.

fluctuated on other predaceous at 5,10 and 15 prey density. No significant difference for the longevity of two predators when fed on levels of 10 and 15 prey individuals. Obtained results nearly similar to that of Sharma and Sadana (1987) who studied the effect of prey densities on the predation rate and daily fecundity of the phytoseiid, Amblyseius finlandicus fed on Eutetranychus orientalis at $27.3-30.5^{\circ} \mathrm{C}$; the number of consumed prey increased with increase of predator density; at predator: prey ratios of 1: 10 to 1 : 30 but then decreased with increase in predator density. Greco et al. (2005) found significant differences between consumption behaviors of the phytoseiid mite, Neoseiulus californicus and prey densities of T. urticae. When two predaceous females caged together consumption increased with increasing prey.

When preys were scarce at level of 5 prey individuals competition was succeed between predaceous mites. Also P. macropilis fed on some individuals of $T$. capisicum so the total consumption decreased. These results are nearly similar with that of Al-Garhy (2008) who determined daily prey consumption and oviposition rates of the two phytoseiid species E. metwalli and T. capsicum as influenced by competition. Generally competition succeded when prey densities decreased.

\section{REFERENCES}

Abou-Setta, M. A.; Sorrell, R. W. and Childers, C. C. 1986. Life 48: A basic computer program to calculate life table parameters for an insect or mite species. Fla. Entomol., 69: 690-697.

Al-Garhy, T. 2008.Studies on some mite species associated with certain fruit orchards at Sharkia Governorate. M.Sc. Thesis, Fac. Agric., Zagazig Univ., 109pp.

Basha, A. E.; El-Naggar, M. E.; Mostafa, E. M. and El-Garhy, T. A. 2007. Laboratory trials to evaluate the efficacy of the predatory mite species Euseius metwallyi and Typhlodromips capsicum as a biological control agents against the two-spotted spider mite, Tetranychus urticae (Acari: Phytoseiidae: Tetranychidae). J. Agric. Sci. Mansoura Univ., 32 (10): 9701-9709. 
Dicke, M.; Sabelis, M. W.; Jong, M. D. and Alers, M. P. T. 1990. Do phytoseiid mites select the best prey species in terms of reproductive success? Exp. Appl. Acarol., 8:161-173.

Duncan, D. B. (1955). Multiple range and multiple F. tests.Biometrics. 11:1-41.

Greco, N. M.; Sanchez, N. E. and Liljesthrom, G. G. 2005. Neoseiulus californicus (Acari: phytoseiidae) as a potential control agent of Tetranychus urticae (Acari: Tetranychidae) effect of pest/ predator ratio on pest abundance on strawberry. Exp. Appl. Acarol., 37: 57 - 66.

Helle, W. and Sabelis, M. W. 1985.Spider mites, their biology, natural enemies and control.Elsevier, Amsterdam vol. 1B.458 pp.

Sabelis, M. 1990. How to analyze prey preference when prey density varies-a new method to discriminate between effects of gut fullness and prey type composition. Oecologia, 82:289-298.

Sabelis, M. W. and Janssen, A. 1994. Evolution of life history patterns in the phytoseiidae. In: Houck MA, editor. Mites. Chapman \& Hall, 70-98.

Sharma, N. K. and Sadana,G. L. 1987. Effect of predator prey density on the prey consumption and daily rate of egg production of the predatory mite, Amblyseius finlandicus (Oudemans) (Acarina :phytoseïidae). Entomon., 12 (3) :191-195.

Takahashi, F. and Chant, D. A. 1992. Adaptive strategies in the genus Phytoseiulus Evans (Acari: Phytoseiidae): Developmental times. Int. J. Acarol., 18:171-176.

Van de Vrie, M. and Boorsma, A. 1970. The influence of the predaceous mite Typhlodromus potentillae (Garman) on the development of Panonychus ulmi (Koch) on apple grown under various nitrogen conditions. Entomophaga, 15: 291-304.

Zaher, M. A.; Shahira, A. O. El-Bishlawy and Fatma S. Ali. 2007. Some ecological and biological studies on Typhlodrompis swirskii (AthiasHenriot) (Acari: Phytoseiidae). Acarines, 1: 23-27.

Zhang Z. Q. 1995. Variance and covariance of ovipositional rates and development rates in the phytoseiidae (Acari: Mesostigmata): a phylogenetic consideration. Exp. Appl. Acarol., 19:139-146. 